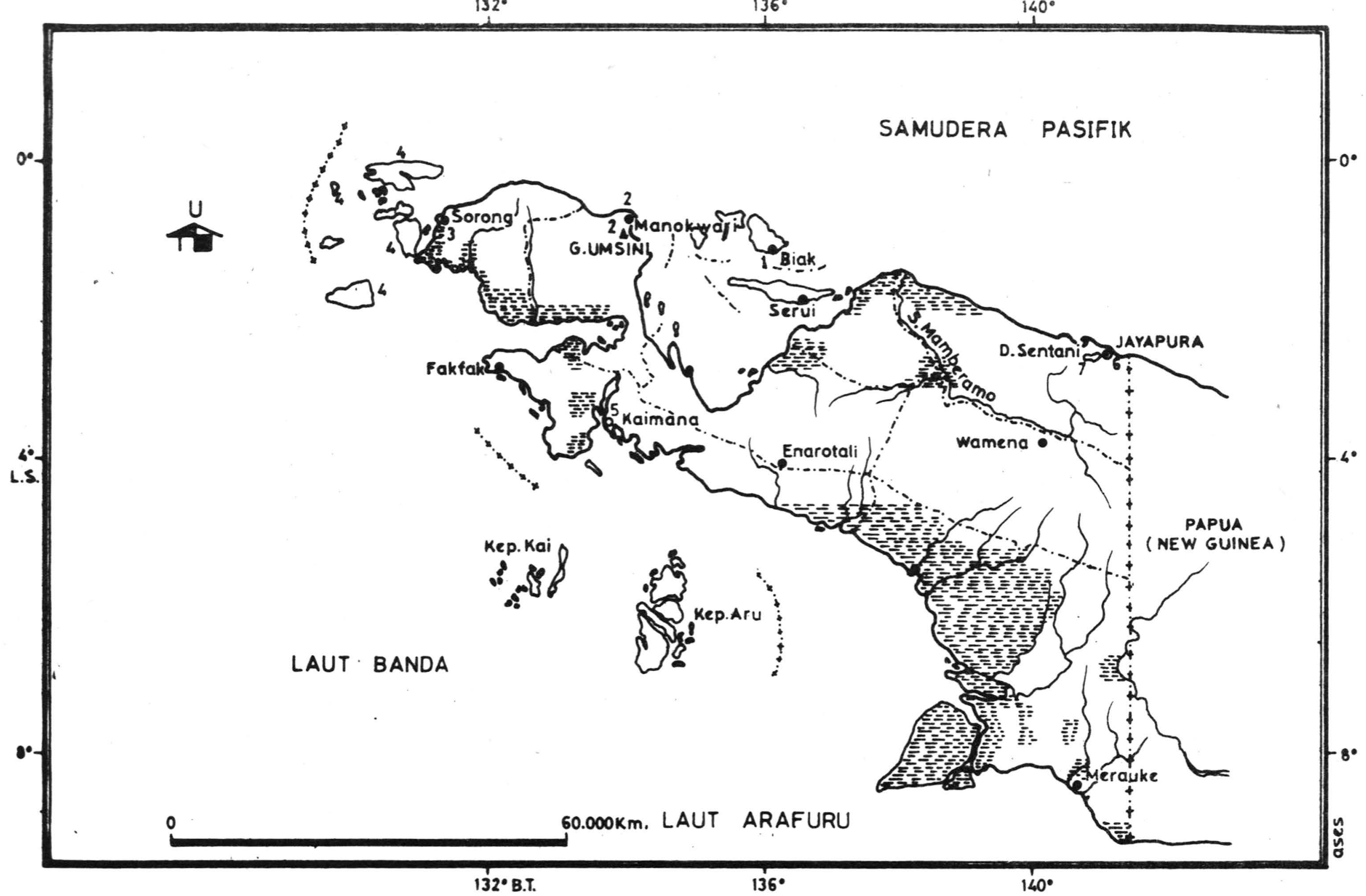

Gambar 1: Peta Irian Jaya

1-7. daerah - daerah penelitian 


\section{SEBUAH CATATAN TAMBAHAN TENTANG PREHISTORI IRIAN JAYA}

\section{Oleh: Goenadi Nitihaminoto}

\section{PENDAHULUAN}

\section{a. Umum}

Tulisan ini saya dasarkan atas tulisan R.P. Soejono yang berjudul Prehistori Irian Barat, ditulis tahun 1963. Tulisan ini dapat ditemukan dalam buku Penduduk Irian Barat dibawah redaksi Koentjaraningrat dan Harsja W. Bachtiar, halaman 39-54: Meskipun tulisan tersebut hanya bersifat kompilatif, rasanya sudah cukup mewakili. Dalam kesempatan ini saya ingin menambahkan tulisan itu berdasarkan hasil penelitian saya bersama Dr. W.G. Solheim II, yang hampir meliputi seluruh Irian Jaya. Dalam tulisan ini nama Irian Barat yang terdapat dalam .tulisan tahun 1963 saya ganti dengan Irian Jaya, sebuah nama yang dipakai sekarang.

Tanggal 31 Juli 1975 saya bersama Saudari Hendari Sofion berangkat ke Jayapura, mendapat tugas mendampingi team Dr. W.G. Solheim II yang akan mengadakan penelitian arkeologi di Irian Jaya. Setelah segala sesuatu persiapan penelitian di Irian Jaya selesai, Hendari Sofion kembali ke Jakarta, tetapi saya baru kembali ke Jakarta pada tanggal 30 Oktober 1975. Kemudian pada bulan Maret 1976 saya bersama Saudara Santoso Sugondo mengunjungi Irian Jaya untuk kedua kalinya dengan tujuan yang sama.

Dalam penelitian tersebut telah dapat kami kunjungi 5 diantara 9 daerah kabupaten yang ada di Irian Jaya.

Daerah-daerah yang saya kunjungi meliputi kabupaten-kabupaten Jayapura, Teluk Cendrawasih, Manokwari, Sorong dan Fak-fak. Pada umumnya Pemerintah Daerah setempat, pejabat-pejabat pemerintah lainnya mémberikan bantuan yang cukup bermanfaat.

Di kabupaten Jayapura kamj mendapat bentuan dari Universitas Cenderawasih, Lembaga Anthropologi Universitas Cenderawasih, Bidang PSK Kantor Wilayah Departemen P dan K Propinsi Irian Jaya dan Perwakilan Freeport Indonesia di Jayapura.

Saudara Z. Karwapi dan Drs. A. Patty menemani kami dalam penelitian di daerah danau Sentani, sedangkan Saudara Irwan Johan sekeluarga dari Perwakilan Freeport Indonesia memberi bantuan yang cukup berharga.

Di Kabupaten Teluk Cendrawasih Saudara Muharramsyah A:A. dari Kantor Departemen P dan K kabupaten Teluk Cenderawasih memberi bantuan yang berharga dan menemani dalam penelitian di daerah tersebut Saudara C. Panjaitan dari Kantor Departemen P dan K kabupaten Sorong, Sdr. Nelson Kansil dari P.T. Pasifik Nikkel Indonesia dan seorang 
pejabat dari Pertamina telah memberikan bantuan dalam penelitian di daerah ini.

Dalam penelitian di kabupaten Fak-fak khususnya di Kaimana kami mendapat bantuan dari Saudara James Arthur dan isterinya Nancy dari P.T. SUNOCO INDONESIA.

Kepada rekan-rekan kami dari Lembaga Anthropologi Universitas Cenderawasih seperti Sdr. Johsz R. Mansobens dan Arnold Cleman Ab hampir selalu menemani kami dalam setiap kegiatan, kami ucapkan terima kasih.

Dalam kesempatan ¡ni saya ucapkan banyak terima kasih pula kepada se mua pihak yang telah membantu penelitian ini, sehingga dapat berjalan dengan lancar dan baik.

\section{b. Sejarah Irian Jaya}

Irian Jaya merupakan daerah Indonesia yang terletak di bagian paling timur dengan perbedaan waktu selama 2 jam dengan daerah Indonesia bagian barat.

Irian Jaya sebelum tahun enampuluhan pernah diduduki Belanda.

Penguasa-penguasa Belanda pertama kali mengadakan usaha menguasai daerah Irian baru pada bulan Juli 1828. Pada waktu itu berlabuhlah kapal Triton dan Iris di sebelah utara kepulauan Aru. Kapal Triton membawa antara lain, A.J. Van Delden, seorang Komisaris Pemerintah yang dikirim oleh Gubernur Belanda di Maluku khusus untuk membangun satu perbentengan yang dapat diduduki oleh kesatuan militer Bèlanda di Irian.

Pada tanggal 24 Agustus 1828 diumumkan bahwa daerah Irian yang mulai pada garis meredian $141^{\circ}$ sebelah timur Greenwich di pantai selatan dan dari tempat tersebut ke arah barat, barat daya dan utara sampai ke semenanjung Goede Hoop di pantai utara, selain daerahdaerah Mansarai, Karondefer, Ambarpura dan Amberpon yang dimiliki oleh Sultan Tidore dinyatakan sebagai milik pemerintah Belanda (Harsja W. Bachtiar, 1963: 57).

Sebagian dari daerah-daerah di Irian Jaya rupa-rupanya juga dianggap merupakan wilayah dari negara nusa Majapahit pada masapemerintahan yang gemilang dari Hayam Wuruk.

Ibu kota Majapahit, dalam masa pemerintahan Hayam Wuruk, didatangi oleh berbagai kepala daerah dari berbagai penjuru kepulauan Indonesia, untuk menyatakan diri tunduk pada maharaja serta mahapatihnya, Gadjah Mada (Harsja W. Bachtiar, 1963: 55).

Bahwa sebagian dari pulau Irian merupakan bagian dari wilayah negara-nusa Majapahit, dinyatakan dalam kitab Negarakertagama, gubahan pujangga Prapánca yang menyelesaikan karyanya ini pada tahun 1365. 
Dalam syair XIV dari kitab maha penting ini dapatlah dibaca, antara lain bait berikut:

Muwah tang i Gurun sanusa mangaram ri Lombok Mirah

lawan tikang i Saksakadi nikalun kahaiyan kabeh

muwah tanah i Bantayan pramuka Bantayan len Luwuk

teken Udamakatrayadhi nikanang sanusapupul

Ikang sakasanusanusa Makasar Butun Banggawai

Kuni Ggaliyao mwang i (ng) Salaya Sumba Solot Muar

muwah tigang i Wandan Ambwan athawa Maloko Ewanin

ri Sran in Timur ning angeka nusatutur

Wwanin, menurut sejumlah sarjana bahasa, ialah nama lain untuk daerah Onin, sedangkan Sran ialah nama lain untuk daeah Kowiai, kedua-duanya daerah di pulau Irian.

Timur mungkin merupakan nama lain untuk pulau Timor tetapı siungkin pula merupakan nama lain unituk daerah bagian timur Irian Jaya. Tidak dapat disangkal bahwa beberapa daerah di Irian Jaya dalam abad XIV dianggap merupakan bagian dari wilayah kedaulatan negaranusa Majapahit. (Harsja W Bachtiar, 1963: 56).

\section{Asal nama Irian}

Irian Jaya adalah nama yang terakhir untuk menyebut pulau Irian di bagian barat. Sebelum itu namanya adalah Irian Barat. Tetapi jauh sebelumnya banyak juga sebutan yang diberikan orang untuk menamakan pulau ini.

Adapun Irian sendiri rupa-rupanya mempunyai arti yang berbeda-beda dalam berbagaí bahasa di Irian Jaya.

Misalnya dalam bahasa Biak-Numfor irian akan berarti "tanah panas" (iri = tanah; an = panas); dalam bahasa Serui irian berarti "tanah air" (iri = tiang pokok; an = bangsa); dalam bahasa Merauke, irian akan berarti "bangsa utama" firi = angkat; an $=$ bangsa) dsb. Lepas dari arti perkataannya dalam berbagai macam bahasa di Irian Jaya sangat berbeda satu dengan yang lain, sebutan ini katanya sudah lama dikenal oleh orang-orang Indonesia yang merantau ke daerah pantai utara di Irian (Koentjaraningrat, 1963: 4).

Sebutan Nieuw Guinee yang dipakai oleh orang Belanda asal dari seorang pelaut Spanyol yang bernama Ynigo Ortiz de Retes yang pernah mengunjungi pantai utara Irian Jaya dalam tahun 1545 dan mem. beri nama Nueva Guinea (Guinea Baru) kepada pantai itu. Kemudian sebutan dari de Retes tadi tampak di peta-peta dari abad XVI, dalam bentuk latinnya ialah Nova Guinea. Dalam peta-peta Belanda dipakai kadang-kadang Nieuw Guinea, kadang-kadang Nieuw Guinee.

Lain sebutan yang kadang-kadang dipakai juga di peta-peta adalah Papua atau variasi-variasi lain dari kata itu. 
Sebutan itu malahan lebih tua dari sebutan Nueva Guinea dan pertamatama dipakai oleh seorang pelaut Portugis, Antonio d'Abreu, yang mengunjungi pantai Irian Jaya pada tahun 1551. Kemudian nama itu juga dipakai oleh pelaut terkenal, ialah Antonio Pigafetta, yang ikut Magelhaes dalam perjalanannya mengelilingi bumi dan yang berada di laut Maluku kira-kira sekitar tahun 1521. Kata papua rupa-rupanya berasal dari pua-pua, suatu kata melayu yang berarti "keriting". Nama Pa pua rupa-rupanya tidak disenangi oleh penduduk Irian pada umum. nya, karena mengandung suasana menghina (Koentjaraningrat, 1963: 4).

Padakonferensidi Milano bulan Juli 1946, menurut J. van Eechoud, diusulkan unfuk pertama kali agar nama Papua, yang dianggap oleh beberapa orang sebagai suatu nama yang memuat unsur merendahkan penduduk pribumi Irian Jaya, diganti dengan nama Irian. Nama Irian diusulkan oleh Frans Kasiepo, yang dianggap mewakili daerah Irian Jaya dalam konferensi Maiino dan diambil alih dalam pemberitaan oleh pegawai dinas penerangan Belanda sehingga dikenal oleh orangorang di luar ruang konferensi Malino (Harsja W. Bachtiar, 1963: 80). Nama Irian kemudian digunakan oleh pemerintah Republik Indonesia dan oleh karena itu dilarang pemakaiannya oleh pemerintah jajahan Belanda (Harsja W. Bachtiar. 1963: 81).

\section{d. Lingkungan}

Luas wilayah Irian Jaya lebih dari pada tiga kali luas pulau Jawa, hampir seluas pulau Sumatra.

Di Irian Jaya pada waktu ini keadaan daratan yang mewujudkan daerahdaerah pegunungan-yang berlereng curam, sungai-sungai yang berair deras, hutan rimba di daerah pedalaman dan daerah rawa di pantai selatan, belum memungkinkan lalu lintas antara daerah tanpa banyak menghadapi kesukaran. Belum banyak daerah-daerah pedalaman yang dapat dikunjungi dengan mudah.

Pada tahun 1955 hanya ada tujuh kota yaug berpenduduk lëbih dari pada 1.500 orang, yaitu Kota Baru (sekarang Jayapura), Sorong, Biak, Merauke, Fak-fak dan Serui (Harsja W. Bachtiar, 1963: 96).

Formasi batu-batuan pembentuk tanah Irian Jaya pada umumnya terdiri atas batu-batuan dari jaman tertier, bahkan ada yang lebih tua lagi, yaitu dari jaman Kapur dan Yura. Terutama terdiri dari batubatuan sedimen seperti sandstone, mergel dan batu kapur. Vulkanisme dari jaman tertier memberikan pula batu-batuan beku seperti andesit dan basalt serta batu-batuan dalam seperti granit, diorit dan diabase. Batu-batuan vulkanis terutama terdapat. di sepanjang pantai utara dari jasirah Kepala Burung (pegunungan Tamrau) dan sepanjang pan. tai bagian barat-laut teluk Sarera (pegunungan Arfak). Juga dapat ditemui pula di pulau-pulau Sulawesi, Batanta, Waigeo, Yapen dan Biak. 
Kecuali batuan dari jaman Tertier, batu-batuan endapan dari jaman Kwarter merupakan batuan yang tersebar luas di Irian Jaya.

Satu-satunya gunung berapi di Irian Jaya ialah gunung Umsini yang terletak di jasirah Doberai di dekat Manokwari (gambar: 1). Oleh karenanya di Irian Jaya boleh dikatakan tidak terdapat tanah tuf dari debu dan lelehan gunung berapi (Gunawan Wiradi \& Sugeng Handjojo, 1962: 33 - 34).

\section{PENELITIAN TERDAHULU}

Beberapa penulis mengenai kepurbakalan Irian Jaya antara tahun 1935 - 1960 adalah H. Aufenanger, J.V. de Bruyn, W.J. Cator, J.E. Elmberg, K.W. Galis, A.N.J.T. van der Hoop, J.J. Murphy, W.A. Mijsberg, H. Riesenfeld, H. de Roder, J. Roder, W.G. Solheim II, G.L. Tichelman, L.G. Vial dan B.A.G. Vroklage. Diantara penulis-penulis itu yang paling banyak menulis tentang kepurbakalan di Irian Jaya ialah K.W. Galis kemudian J. Roder. Pada umumnya kedua penulis tersebut tertarik pada lukisan-lukisan dinding gua atau lukisan pada dinding ceruk tebing.

Hasil-hasil penelitian tersebut dapat dikelompokkan sebagai berikut:

\section{Benda-benda Mesolithik}

Benda-benda yang dapat digolongkan kategori mesolithik adalah flakes, pecahan tembikar, alat-alat penggaruk (scrapers), mata panah dan lukisan-lukisan dinding gua dari gaya Tabulinetin.

Alat-alat batu seperti flakes yang dikerjakan pada pinggir-pinggirnya (retouched flakes) dan pecahan-pecahan tembikar serta alat penggaruk (scrapers) ditemukan oleh J. Roder pada tahun 1937 di gua Dudumunir di pulau Arguni.

Alat-alat itu ditemukan pada kedalaman antara-2 meter sampai dengan - 3,60 meter di bawah permukaan tanah (R.P. Soejono, 1963: 40).

Lukisan-lukisan dinding gua dàri gaya Tabulinetin (Kokas, teluk Berau) berwarna merah, terutama berupa cap-cap tangan dan kaki (hand-and footstencils) yang persamaannya dapat ditemukan di lukisan dinding gua di Maros, Sulawesi Selatan (R.P. Soejono, 1963: 42). Di tempat-tempat ini juga ditemukan motif-motif gambar orang, ikan, binatang melata (kadal), yang bentuknya distilir (R.P. Soejono, 1963: 49).

\section{Benda-benda Neolothik}

Benda-benda neolithik di Irian Jaya berupa pecahan barang tembikar, kapak lonjong dan kapak persegi. Pecahan barang tembikar yang berwarna merah, pembuatannya kasar dan kadang-kadang diberi hiasan sederhana dapat dikategorikan pada benda-benda neolithik. Pecahan-pecahan tembikar tersebut ditemukan di gua Dudumunir 
(pada lapisan atas), Ayambori (sekitar Manokwari), pulau Awar (teluk Geelvink), semenanjung Tiachnuch (dekat Jayapura) dan Sabron (barat laut danau Sentani).

Selain kapak lonjong yang merupakan kebudayaan khas Irian Jaya terdapat unsur-unsur kebudayaan kapak persegi yang telah menyebar jauh di daerah pedalaman. Kapak-kapak persegi yang berbentuk gepeng, panjang dan besar masih dipergunakan di daerah gunung Hagen (Irian Tengah) sebagai kapak perang atau kapak upacara. Kapak-kapak ini dan beberapa papan batu lainnya (blades) diberi lubang dengan tehnik penggurdian (boring) yang khusus. Metode penggurdian alat-alat batu adalah ciri khusus dari neolithik akhir dan tehniknya mula-mula dikembangkan di Tiongkok (kebudayaan Yang Shao) serta dipergunakan acapkali di Filipina. Benda-benda tadi asing bagi suku-suku bangsa pedalaman dan dipandang sebagai pemberian nenek moyang. Sebab dianggap mempunyai kekuatan gaib, barang-barang itu menjadi pemujaan mereka (R.P. Soejono, 1963: 42-43).

\section{Kebudayaan Megalithik}

Bangunan-bangunan batu seperti kubur-kubur, tembok-tembok perbentengan dan tempat-tempat persajian tersebar di pulau-pulau kecil (Adi, Namatote, Patipi, Fu-um, Ora, Batanta, Sorong, Numfor) dan di pantai-pantai sebelah barat (sekitar sungai Karufa di Skroe, Sisir, Bintuni), menunjukkan corak kebudayaan megalithik di kepulauan Indonesia lain. Unsur-unsur pengaruh lain dari arus megalithik ini ialah dongeng-dongeng suci tentang nenek moyang yang kawin dengan bidadari dari langit (terdapat di daerah Mamberamo), kemudian lesung-lesung batu (di Sorong dan Sentani) dan patung-patung nenek moyang (R.P. Soejono, 1963: 43).

\section{Benda-benda perunggu.}

Benda-benda perunggu yang ditemukan di Irian Jaya, yaitu kapak, mata tombak dan tympanon nekara. Kapak perunggu tersebut terdiri dari kapak corong, kapak yang berbentuk kipas pada mata kapaknya (convex). Sebagian besar temuan benda-benda perunggu terdapat di sekitar danau Sentani, yaitu di Asei, Kwadeware, Abar dan Ifar kecil.

Di Asei dan Kwadeware pernah ditemukan kapak corong dari tipe umum (socketed bronze axe). Di Abar terdapat fragmen sebuah kapak upacara, berupa mata kapak yang berbentuk bulat dari tipe monstrans dan di Ifar kecil ditemukan sebuah kapak perunggu tipe Marweri Urang.

Temuan benda-benda perunggu di Sentani mempunyai keunikan, yaitu temuan dua buah mata tombak bertangkai pádat (masif) dan berlubang untuk memperkuat ikatan dan mata kapak berbentuk kipas(convex). 
yang melebar: Tangkai-tangkai kapak berlubang, begitu pula pada salah satu'mata kapaknya.

Di luar daerah, Sentani ditemukan sebuah kapak corong, yang mirip dengan jenis kapak perunggu di Tiongkok dan sebuah kapak lain terdapat di Hufmare di daerah hulu sungai Koor (timur-laut Sorong). Di sekitar danau Aimaru (daerah suku bangsa Mejbrat) tiga buah tympanon nekara perunggu yang pada pusatnya mempunyai hiasan bintang yang berjari duabelas, yang dapat digolongkan nekara tipe Heger I, yang merupakan tipe nekara umum di Indonesia (R.P. Soejono, 1963: 45-48).

Benda-benda perunggu bagi suku-suku bangsa di Irian Jaya merupakan barang-barang ajaib yang mengandung kekuatan sakti dan yang dihubungkan dengan asal usul nenek moyang. Menurut kepercayaan mereka benda-benda perunggu di Marweri Urang telah dibawa turun dari langit oleh tokoh nenek moyang bernama Marweri Urang; kapak di Ifar kecil mereka namakan daimeholo (nama jenis burung) dan dibawakan oleh nenek moyang penduduk sana; tympanon-tympanon oleh orang Mejjbrat dinamakan bori (barang sakti) dan bo so napi (old thing Mother) dan pecahan-pecahan perunggu dari tympanon-tympanon tersebut dipergunakan sebagai jimat (R.P. Soejono, 1963: 48).

Pengaruh unsur-unsur kebudayaan Dongsong telah mencapai Irian Jaya sesudah perkembangan unsur-unsur megalithik. Misalnya di Marweri Urang, dimana tingkat megalithikum akhir telah menerima pengaruh-pengaruh kebudayaan perunggu yang tiba kemudian, sehingga unsur-unsur megalithik dan unsur-unsur Dongsong telah diketemukan di tempat yang satu itu. (R.P. Soejono, 1963: 49).

\section{Kebudayaan-kebudayaan Prehistori yang masih hidup}

Suku bangsa Timorini merupakan salah satu suku bangsa yang hidup di daerah pegunungan tengah di pedalaman Irian Jaya, yang masih hidup dalam tingkat kebudayaan Neolithik (R.P. Soejono, 1963: 50).

Kapak batu orang Timorini digunakan sebagai alat bercocok tanam. Kapak batu tersebut terdiri dari 2 macam, yaitu yara dan yao. Yara khusus dipakai oleh orang laki-laki sedang yao dipakai oleh perempuan (Koentjaraningrat, 1963: 221 - 222).

Tingkat kebudayaan suku bangsa yang hidup di beberapa daerah pegunungan tengah di pedalaman Irian Jaya, kita golongkan dalam ka. tegori "kebudayaan neolithik hidup" dan (leitfossil) daripada kebudayaan ini adalah kapak batu yang berpenampang lintang lonjong, sebuah alat yang dipergunakan sehari-hari(R.P. Soejono; 1963: 51). 


\section{HASIL-HASIL PENELITIAN}

Hasil penelitian kami di Irian Jaya berupa alat-alat dan perhiasan dari kerang, lukisan pada dinding tebing, kubur ceruk tebing (burial ledge), kapak batu, kreweng (pecahan tembikarpotsherds), kebudayaan megalithik, benda-benda perunggu dan tradisi-tradisi prehistori.

\section{Alat-alat dan perhiasan dari kerang}

Alat-alat yang terbuat dari kerang, merupakan alat kepentingan sehari-hari seperti alat penggaruk (scrapers) dan perhiasan. Alatalat penggaruk (scrapers) yang terbuat dari batu, tulang atau kerang oleh Van Heekeren dimasukkan dalam mesolithik, seperti halnya temuan alat-alat kerang dari Gua Gede di Tuban (H.R. van Heekeren, 1972: 100 - 101).

Alat-alat kerang yang kami jumpai di Irian Jaya berupa penggaruk (scrapers) dan perhiasan. Alat-alat tersebut kami temukan di kampung Padwa, kabupaten Teluk Cenderawasih. Alat penggaruk (scrapers) dari kampung Padwa ditemukan dalam penggalian, yang berasal dari kedalaman -40 Cm sampai dengan -70 Cm di bawah permukaan tanah. Lokasinya terletak di dataran tebing di atas laut. Panjang alat penggaruk itu ialah $6 \mathrm{Cm}$, lebar 1,5 Cm dan tebal $1 \mathrm{Cm}$. Selain itu kami temukan perhiasan yang terbuat dari kerang yang mungkin dipergunakan sebagai hiasan hidung atau telinga (gambar: 2).

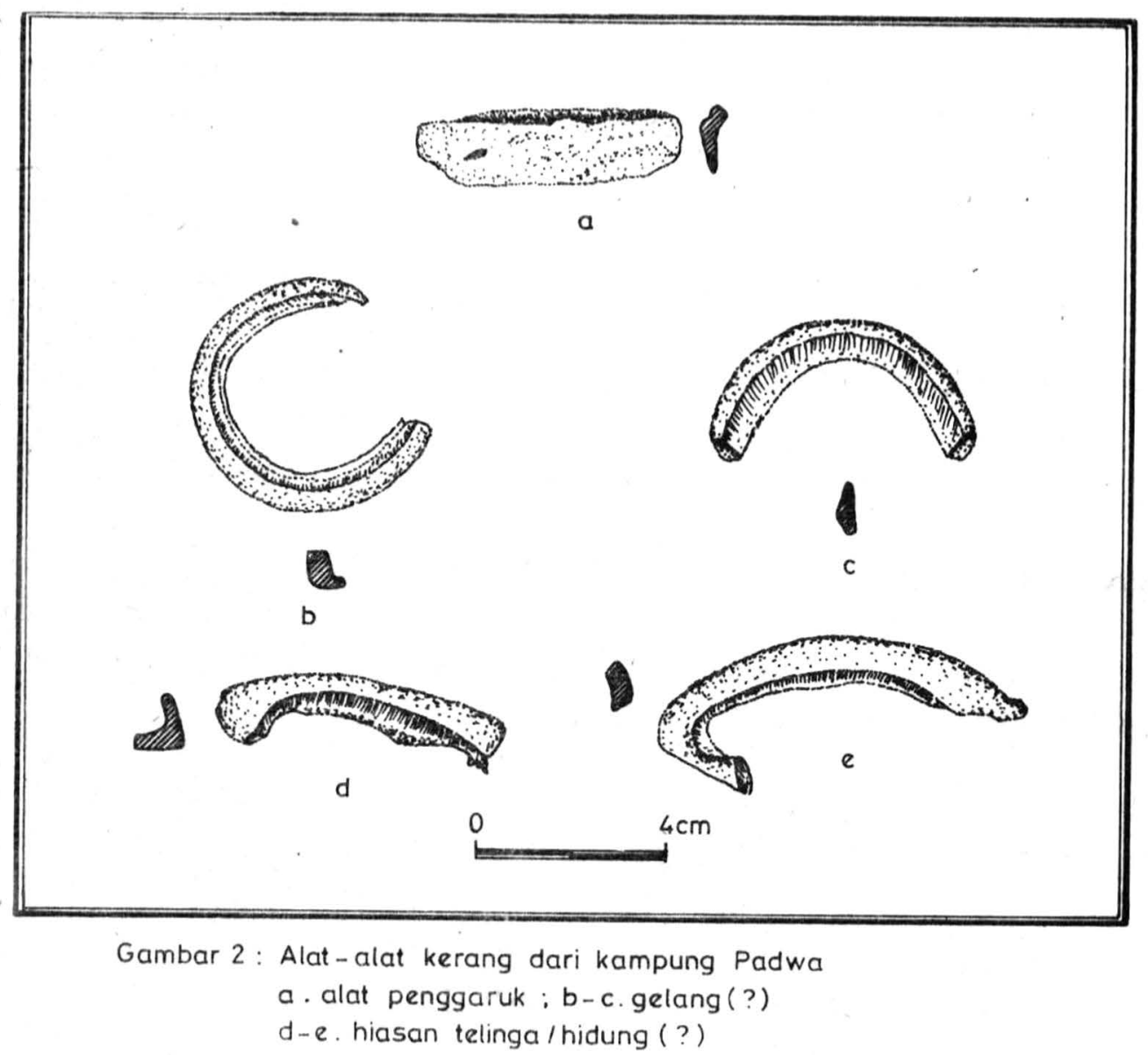




\section{Lukisạn dinding tebing/ceruk tebing}

Meskipun belum dapat dipastikan, makajlukisan-lukisan yang terdapat pada dinding tebing atau dinding ceruk tebing (clift painting) serta lukisan tebing batu (rock painting) dalam kronologi prasejarah Indonesia oleh van Heekeren dimasukkan ke dalam periode mesolithik (H.R. van Heekeren, 1972: 129).

Di pulau Waigeo utara, lukisan itu kami temukan pada sebuah tebing batu di tepi sebuah sungai di kampung Asokwir. Penduduk setempat menyebut lukisan itu sapormerek (sapor = tanjung: merek = gambar) yang berarti tanjung bergambar.

Lukisan itu berwarna putih, terletak \pm 6 meter di atas permukaan tanah. Lukisan tersebut terdiri dari 4 gambar yang terbagi ke dalam dua deret, yaitu deretan atas dan bawah. Keadaannya sudah hampir rusak, sehingga salah satu gambarnya sudah tidak jelas lagi. Deretan atas terdiri dari dua gambar, demikian juga halnya pada deretan bawah. Apabila diperhatikan, lukisan itu merupakan gambar burung yang digayakan, sehingga tampak lebih sederhana.

Di Kaimana lukisan-lukisan tebing atau ceruk tebing kami temukan di sepanjang tanjung Bitcari, kampung Sisir I dan kampung Mai-mai. Di tanjung Bitcari, lukisan itu ditemukản pada dua tempat, yang keduanya terletak di atas laut. Lukisan pertama jaraknya \pm 30 menit dengan perahu motor dari Kaimana. Lukisan itu terdiri dari 4 buah gambar, tiga diantaranya berupa kerangka manusia yang digayakan, sedang lainnya merupakan gambar abstrak. Bagian kepala mempunyai tiga buah tanduk, sedangkan bagian badannya merupakan gambaran alat kelamin lelaki yang digayakan. Gambar-gambar itu pada bagian atasnya dihiasi dengan lingkaran-lingkaran kecil. Lukisan itu menggunakan dua macam warna, yaitu merah dan kuning (gambar: 3).

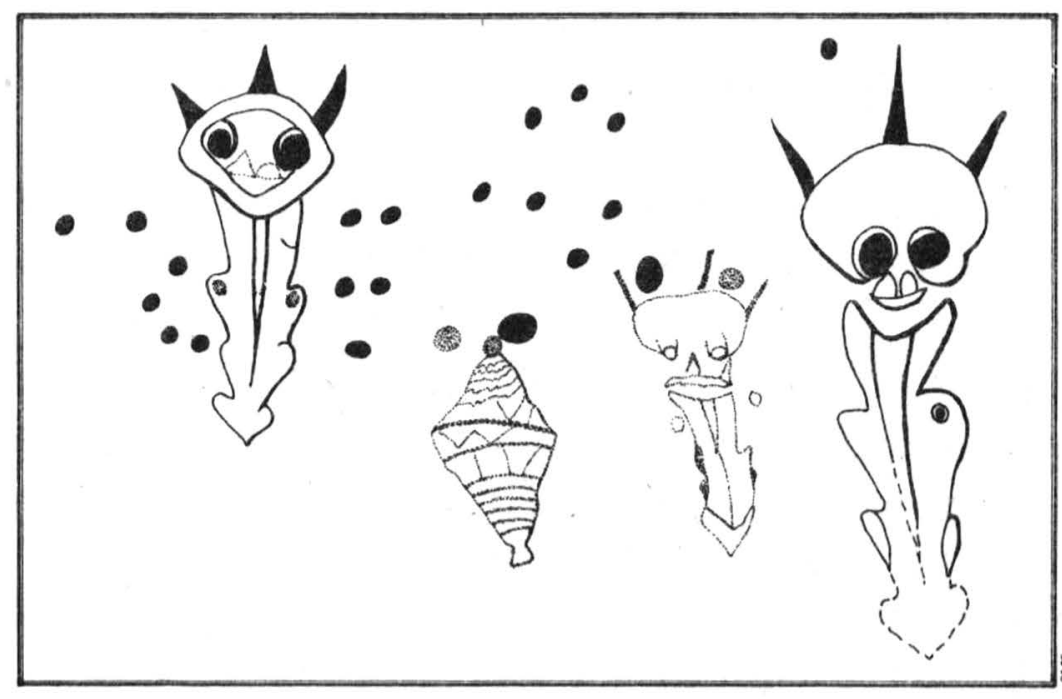

Gambar 3 : Lukisan dinding Ceruk Tebing Tanjung Bitcari (Kaimana)

- warna merah -... warna kuning 
Lukısan kedua yang terdapat di tanjung Bitcari, terletak di dinding ceruk tebing, jurusan ke kampung Sisir I. Lukisan ini menghadap ke timur dengan ketinggian \pm 20 meter di atas permukaan air laut sehingga sukar diamati dengan mata telanjang. Lukisan-lukisan itu memakai warna merah dan tidak terdapat warna kuning, dengan gambargambar seperti binatang melata, pohon, perahu, dua buah cap tangan (ha nd stencils), gambar orang dengan bentuk sederhana dan gambar matahari (gambar: 4).

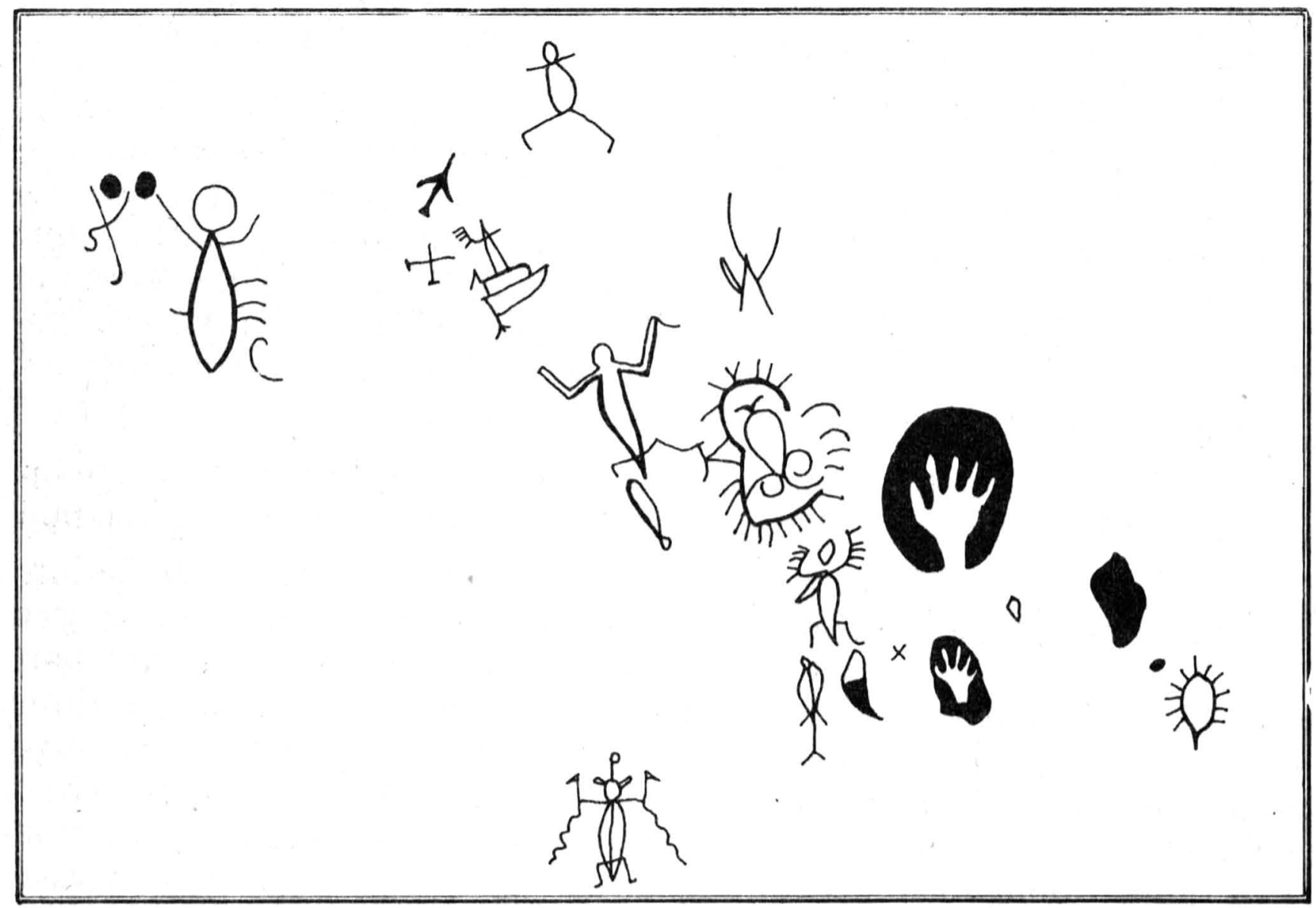

Gambai 4: Lukisan dinding Ceruk Tebing yang kedua di Tanjung Bitcari,

menggunakan warna merah tanpa warna kuning

Lukisan dinding ceruk tebing yang terdapat di kampung Sisir I bersifat abstrak dengan menggunakan warna merah dan sebagian kecil warna kuning.

Lukisan-lukisan itu sudah banyak yang rusak dan gambar-gambar yang masih dapat dikenali yaitu bentuk hewan, jala, ikan, tumbuh-tumbuhan dsb. (gambar: 5).

Di kampung Mai-mai lukisan dinding tebing (cliff painting) terdapat di 5 tempat yang kesemuanya terletak di tebing yang tinggi dan panjang. Lukisan tebing yang pertama semuanya berwarna merah, sedangkan empat lainnya mempunyai warna merah dan kuning. Gambar yang terlukis ialah orang terlentang dengan kaki terpotong, orang hamil yang sedang terlentang (mungkin akan melahirkan), anak di dalam sangkar, gambar muka orang yang bulat dengan sinar di seke- 


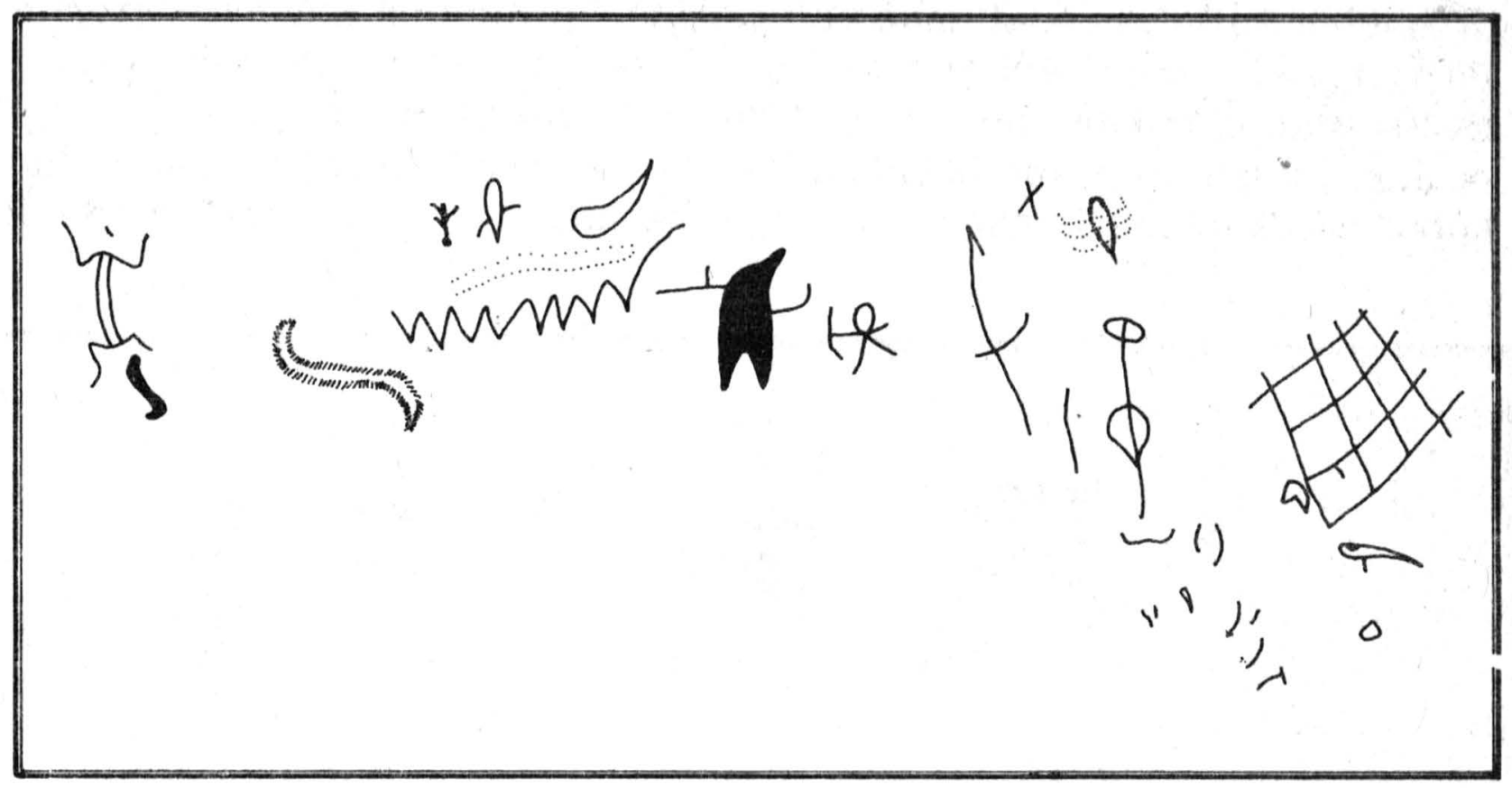

Gambar 5: Lukisan dinding Ceruk Tebing dikampung Sisir I (Kaimana) dengan warna merah dan kuning (

lilingnya, orang yang sedang berburu, cap tangan lengkap dengan kelima jarinya yang dilukis dengan warna kuning, gambar-gambar hewan dan sebagainya.

Lukisan-lukisan itu sudah tidak diketahui lagi asal usulnya oleh penduduk, hanya mereka masih mempunyai dongeng tentang lukisanlukisan tersebut. Di beberapa tempat lukisan-lukisan ini disebut ambersibui (ditulis oleh orang-orang asing), karena mereka tidak mengenal adat yang bertalian dengan lukisan-lukisan tersebut. Menurut ceritera kepercayaan penduduk cap tangan dan kaki itu adalah bekasbekas yang ditinggalkan oleh nenek moyang pertama yang buta. Mereka datang dari arah matahari terbit dan dalam perjalanan ke arah barat mereka meraba-raba dinding-dinding gua itu, sehingga meninggalkan bekas-bekasnya.

Lukisan-lukisan itu dibuat bertalian dengan upacara-upacara kesuburan, penghormatan nenek moyang, inisiasi atau mungkin pula untük keperluan upacara ilmu dukun, untuk meminta hujan dan kesuburan, seperti halnya sekarang pada suku-suku bangsa di Australia. Kemungkinan lain yaitu bahwa lukisan-lukisan itu untuk memperingati kejadian-kejadian penting yang telah dialami (R.P. Soejono, 1963: 49).

\section{Kubur ceruk tebing (burial ledge)}

Diantara daerah-daerah di Irian Jaya yang pernah kami kunjungi, daerah Biak merupakan tempat yang banyak ditemukan kubur ceruk tebing. Kubur ceruk tebing yang terdapat di daerah ini terletak di kampung Samber dan Padwa. Beberapa kubur ceruk tebing yang terdapat 
di Samber yaitu yen soaf, mno babo, oribab, pirdomun dan karosarwam. Pał a kubur ceruk tebing tersebut ditemukan barang-barang seperti manik-manik, noken, peti mayat, korwar, tulang-tulang manusia dan peiiuk, yang merupakan bekal kubur. Periuk-periuk yang terdapat dalam kubur ceruk tebing Samber ini mempunyai hiasan yang bagus (gambar: 6).

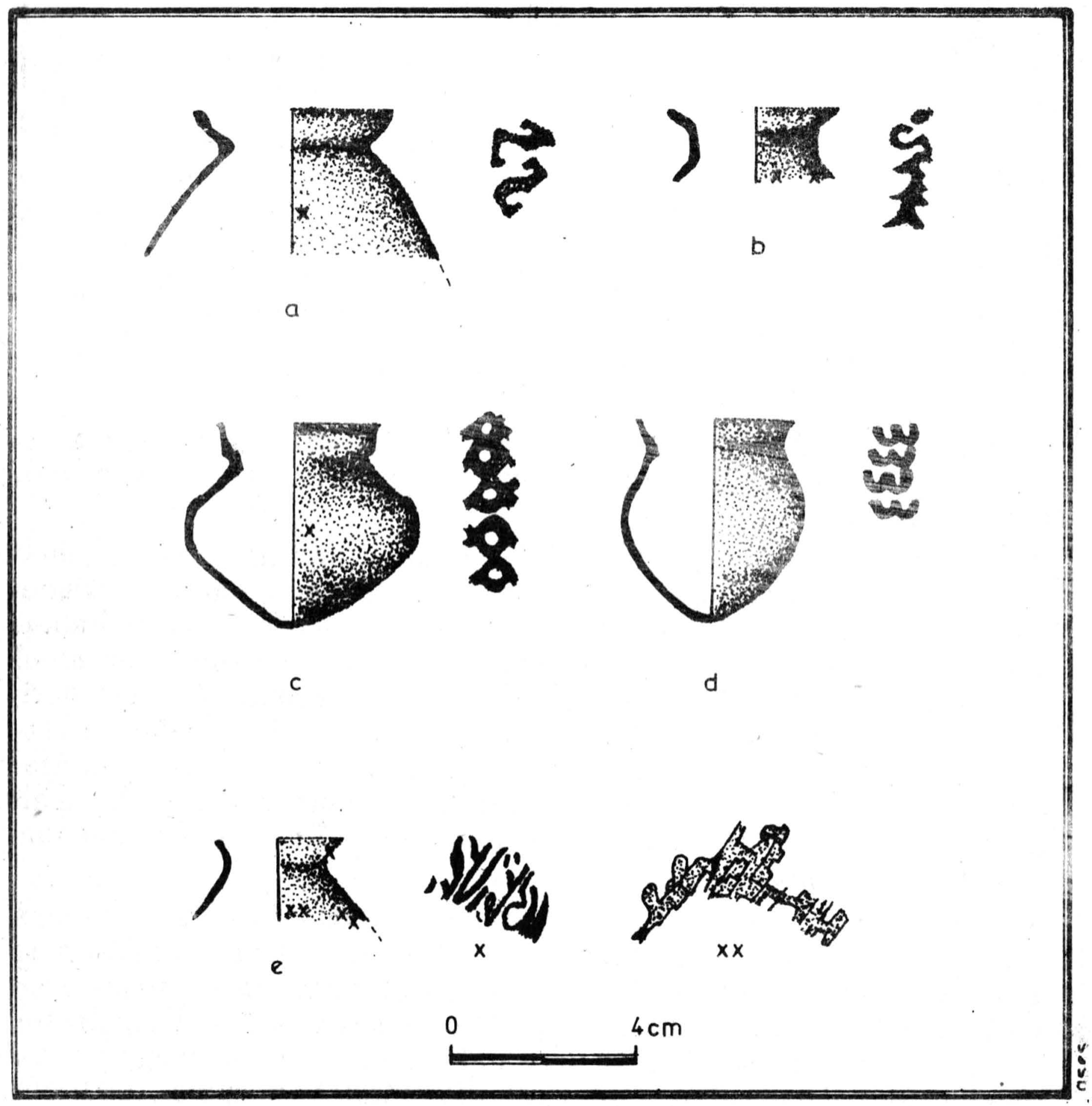

Gambar 6 : $a-d=$ periuk-periuk dari Kubur Ceruk Tebing Pirdomun (Samber)

$e=$ periuk dari Kubur Ceruk Tebing Oribab (Samber)

$x=$ letak hiasan pada periuk 
Di Padwa terdapat juga kubur ceruk tebing, yang mempunyai barang-barang yang hampir sama dengan kubur ceruk tebing di Samber dan selain itu tikar (anyaman) dipergunakan sebagai pembungkus mayat.

\section{Kapak batu}

Tempat temuan kapak batu selama penelitian ini ada di dua tempat, yaitu di kampung Padwa dan di Kaimana. Kapak batu yang ditemukan di Padwa sebanyak tiga buan, satu diantaranya merupakan temuan permukaan (gambar: 7 . a) sedangkan yang lain merupakan temuan penggalian (gambar: 7. b.c.). Kapak batu yang ditemukan di permukaan mempunyai penampang empat persegi panjang. Sedang dua buah kapak lainnya yang ditemukan dalam penggalian berasal dari kedalaman $-10 \mathrm{Cm}$ di bawah permukaan tanah. Temuan tersebut yang satu berbentuk empat persegi panjang sedangkan lainnya berbentuk bulat lonjong.

Temuan kapak di Kaimana, hanya merupakan pecahannya saja, yang ditemukan dari penggalian di gua Misigura. Pecahan kapak itu ditemukan dari kedalaman - $40 \mathrm{Cm}$ di bawah permukaan tanah. Dari pecahannya menunjukkan bahwa kapak itu sudah diupam.

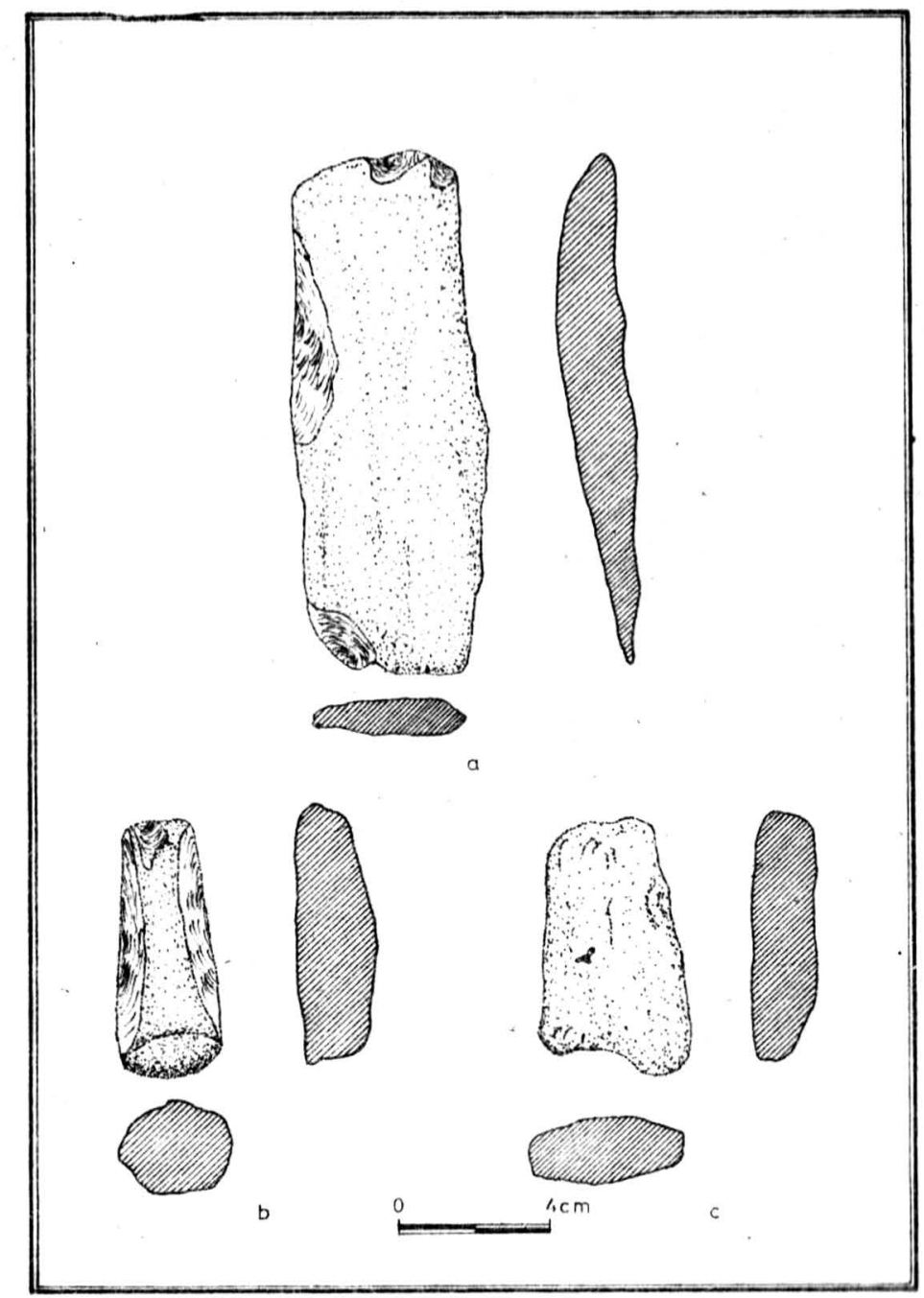

Gambar 7 Kapak batu Padwa

a. temuan permukcan : b-c temuan ekskaves 


\section{Kreweng (pecahan tembikar/potsherds)}

Kreweng ditemukan , tiga tempat, yaitu di daerah Makbon (Sorong), Kaimana dan Padwa. Temuan kreweng di Makbon berasal dari permukaan terutama dari gua-gua Selesimiklagi, vang dihias dengan cara gores (incised) tera (impressed) dan cukilan. Hias gores sebagian besar bermotif garis sejajar, hias tera ada yang bermotif tikar dan cukilan menyerupai tanda koma (gambar: 8):

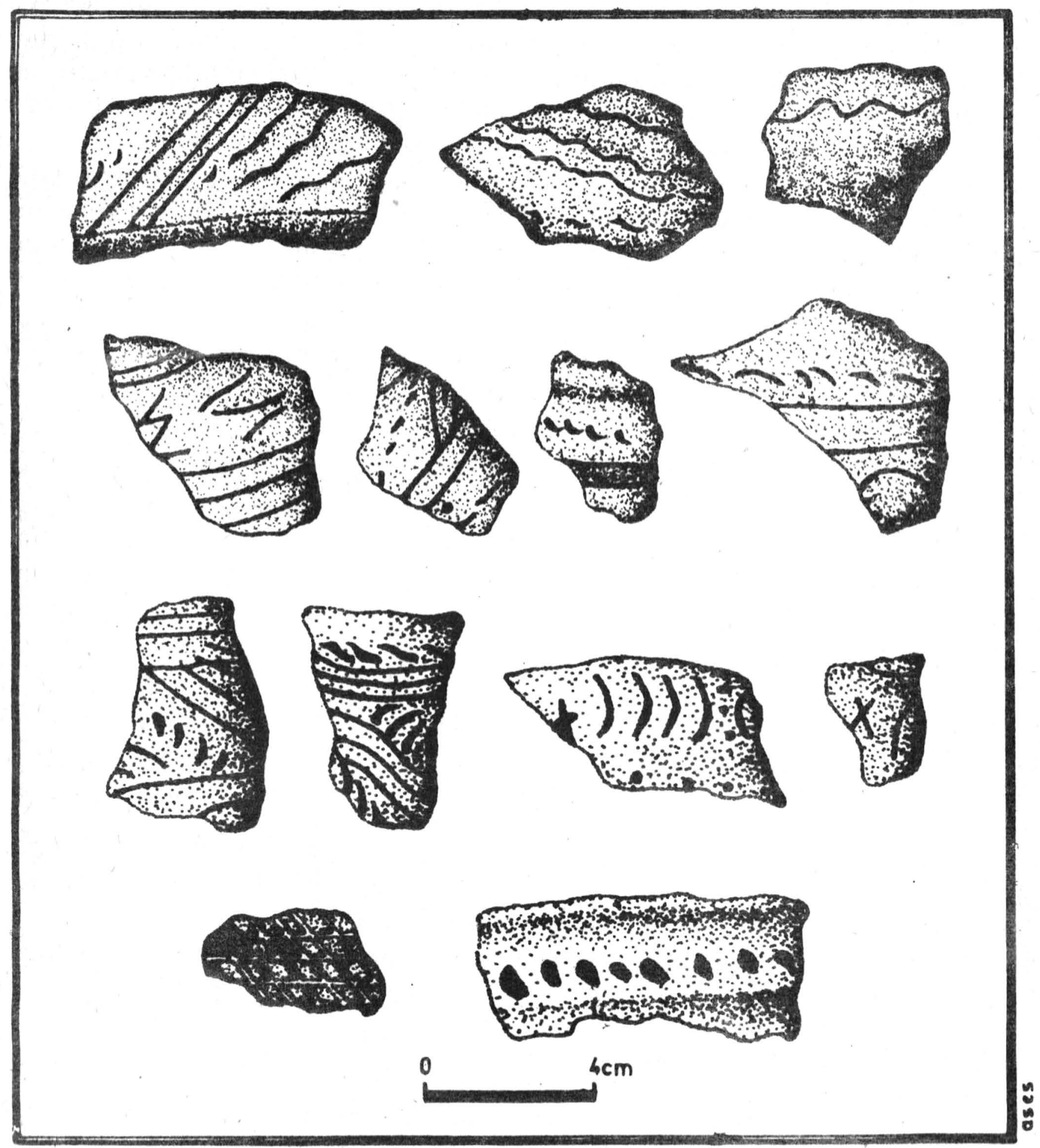

Gambar 8 : Kreweng berhias dari gua Selesimiklagi Makbon(Sorong) 
Kreweng-kreweng berhias yang ditemukan di kampung Padwa merupakan hasil penggalian dari kedalaman antara $-10 \mathrm{Cm}$ sampai dengan - $80 \mathrm{Cm}$ di bawah permukaan tanah.

Hiasan kreweng dibuat dengan cara gores (incised) dan cukilan. Kreweng yang berhias góres bermotif garis-garis gelombang, chevron dan belah ketupat; sedangkan hias cukilan bentuknya seperti tanda koma (gambar: 9 a.b.). Selain itu ditemukan juga kreweng polos (tidak berhias) yang sudah dikerjakan pada bagian tepinya (gambar: 9. c.).

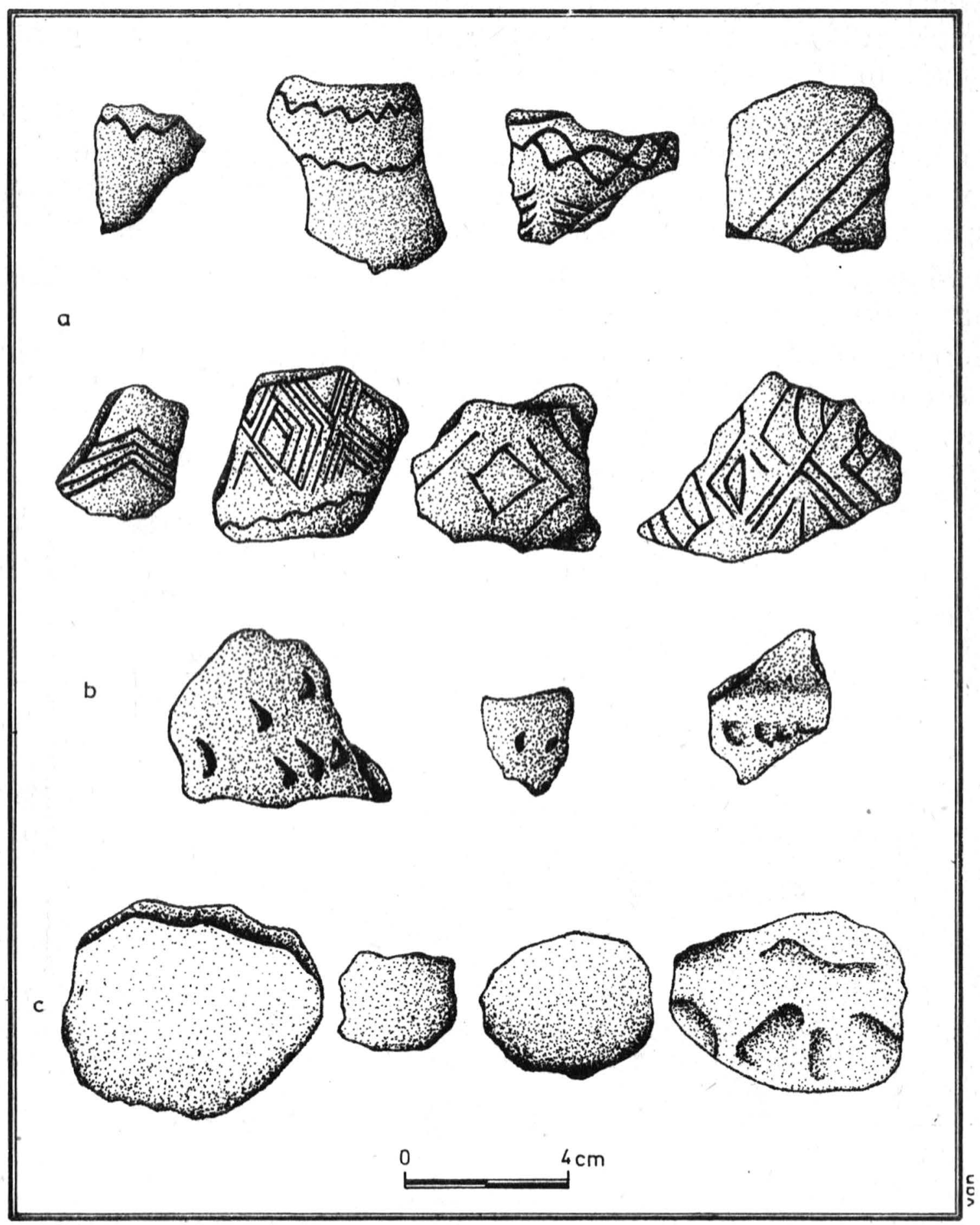

Gambar 9: Kreweng berhias dan gaco kampung Padwa (Biak) 
Bentuk kreweng seperti ini biasa kita jumpai pada ekskavasi di Trowulan (Mojokerto, Jawa"Timur) yang di Jawa biasa disebut gaco. Gaco ini umumnya dipakai sebagai permainan anak-anak, tetapi sementara orang ada yang berpendapat bahwa gaco dipakai sebagai alat timbangan juga.

Ekskavasi di gua Misigura (Kaimana) menemukan banyak sekali kreweng berhias dan polos. Pecahan yang ditemukan sebagian berukuran besar, sedangkan hiasannya hampir sama dengan hiasan-hiasan kreweng yang ditemukan di Padwa dan gua Selesimiklagi. Krewengkreweng itu ditemukan pada kedalaman sampai dengan $-50 \mathrm{Cm}$ di hawah permukaan tanah. Krewieng-kreweng itu ditemukan tidak saja di lantai gua tetapi sampai ke lorong-lorongnya.

Kreweng-kreweng hasil ekskavasi Dr. W.G. Solheim II dari Sendangduka (Kwadeware) menunjukkan cara menghias yang sama, demikian juga motif hiasannya. Kreweng-kreweng tersebut sekarang disimpan di Lembaga Anthropologi Universitas Cenderawasih.

Kreweng-kreweng berhias sebagian besar merupakan hias gores dengan motif garis-garis sejajar, chevron dan garis-garis lengkung (gambar: 10). Kreweng-kreweng tersebut ditemukan sampai dengan kedalaman -50 Cm di bawah permukaan tanah setempat.

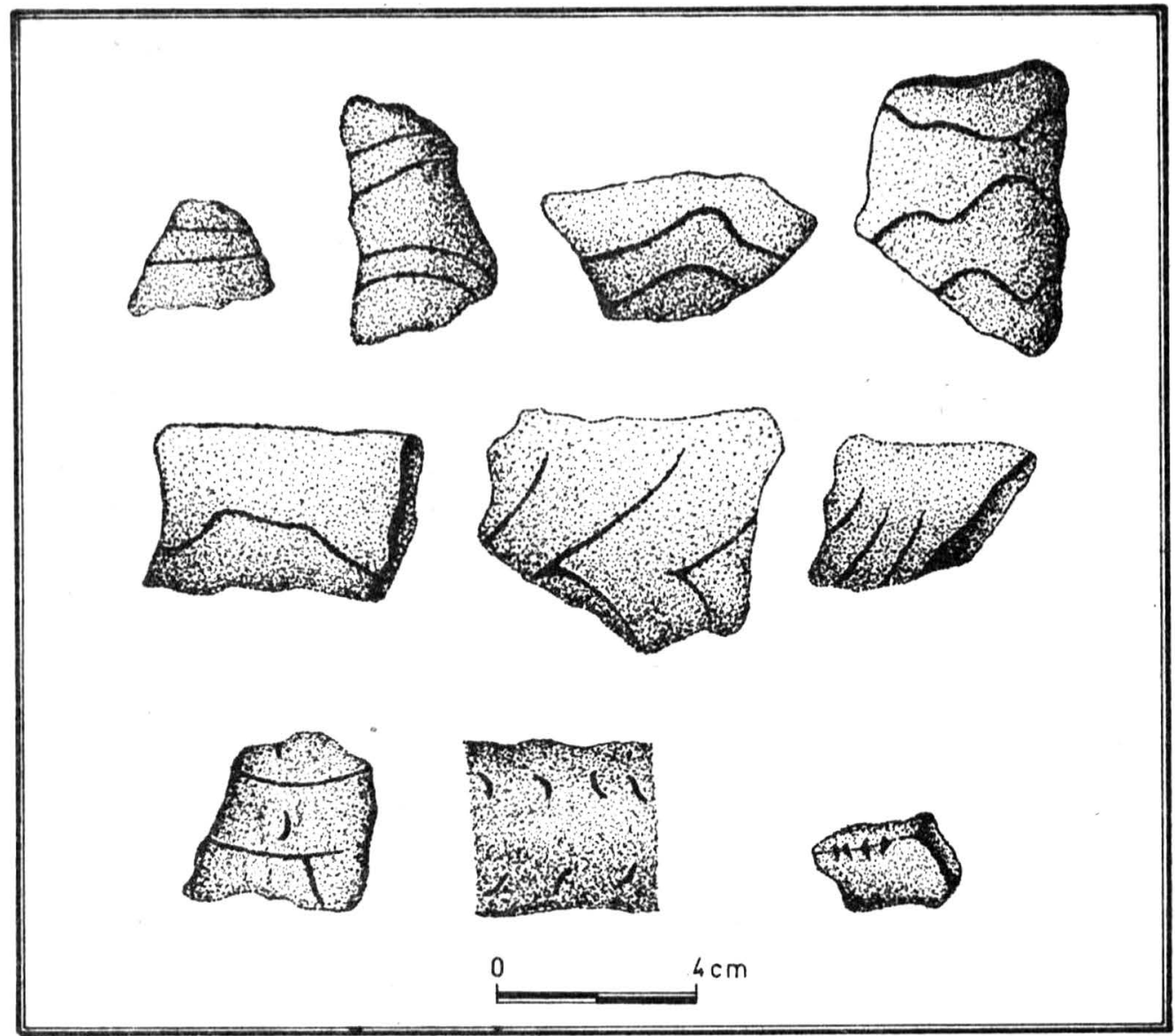

Gambar 10: Kreweng berhias dari Kwadeware(d.Sentani) 


\section{Kebudayaan megalithik}

Peninggalan kebudayaan megalithik kami jumpai di Kwadeware, dekat dengan lokasi penggalian Dr. W.G. Solheim II yaitu di daerah danau Sentani. Peninggalan tersebut berupa lempengan batu yang sebelumnya tergeletak di tempat itu.

Selain itu D.D. Bintarti pada tahun 1979 pernah mengadakan penelitian di kampung Doyo Lama (di tepi danau Sentani) menemukan sisasisa peninggalan megalithik. Peninggalan-peninggalan itu berupa beberapa kelompok batu tegak dengan lukisan warna putih. Pola lukisan itu pada umumnya berupa binatang air seperti ikan dan kura-kura. Lukisan lainnya bermotifkan binatang melata (seperti kadal) dan ada pula yang bermotifkan manusia.

Pada bagian yang lebih tinggi dari daerah itu, terdapat beberapa menhir yang merupakan kelompok dan ada pula yang tidak teratur letaknya (D.D. Bintarti, 1980: 2 - 3).

\section{Benda-benda perunggu}

Benda-benda perunggu yang kami temukan di daerah danau Sentani, yaitu di desa Kwadeware, berupa kapak, f. kapak, pisau dan tangkai pisau.

Kapak perunggu yang masih utuh berukuran panjang 15,3 Cm, lebar $12,2 \mathrm{Cm}$ dan tebalnya $2,4 \mathrm{Cm}$. Di kedua permukaan mata kapaknya terdapat bagian yang cekung (gambar: 11. a). Kapak jenis ini disebut tepa yang disimpan sebagai pusaka.

Kapak perunggu lainnya tinggal bagian mata kapaknya saja, yang berukuran panjang $10 \mathrm{Cm}$, lebar $11,3 \mathrm{Cm}$ dan tebalnya 0,8 Cm (gambar: 11. d). Fragmen kapak ini disebut damu tepa. Pisau perunggu yang masih utuh panjangnya $14 \mathrm{Cm}$, lebar $3,5 \mathrm{Cm}$ dan tebalnya $0,3 \mathrm{Cm}$ (gambar: 11 . b) yang ditemukan bersama benda-benda tersebut.

Tangkai pisau perunggu yang oleh penduduk setempat disebut boi-boi panjangnya $10 \mathrm{Cm}$, lebar 4 - 6,5 Cm dan tebal 1,2 Cm (gambar: 11. c). Barangtbarang itu semuanya disimpan oleh kepala desa (ondoafi) setempat sebagai barang pusaka.

Barang-barang perunggu yang ditemukan di kampung Asei (danau Sentani) telah dibawa ke Negeri Belanda dan bàrang-barang itu berasal dari Kwadeware. Karena dipergunakan sebagai mas kawin, maka barang-barang tersebut pindah ke kampung Asei.

\section{Tradisi prehistori}

Tradisi pembuatan periuk dapat diklasifikasikan kedalam tradisi prehistori yang masih hidup pada masa kini.

Pembuatan periuk di Irian Jaya baru kami jumpai di dua tempat, yaitu di pulau Mansinam (Manokwari) dan di Abar (danau Sentani). Meskipun 


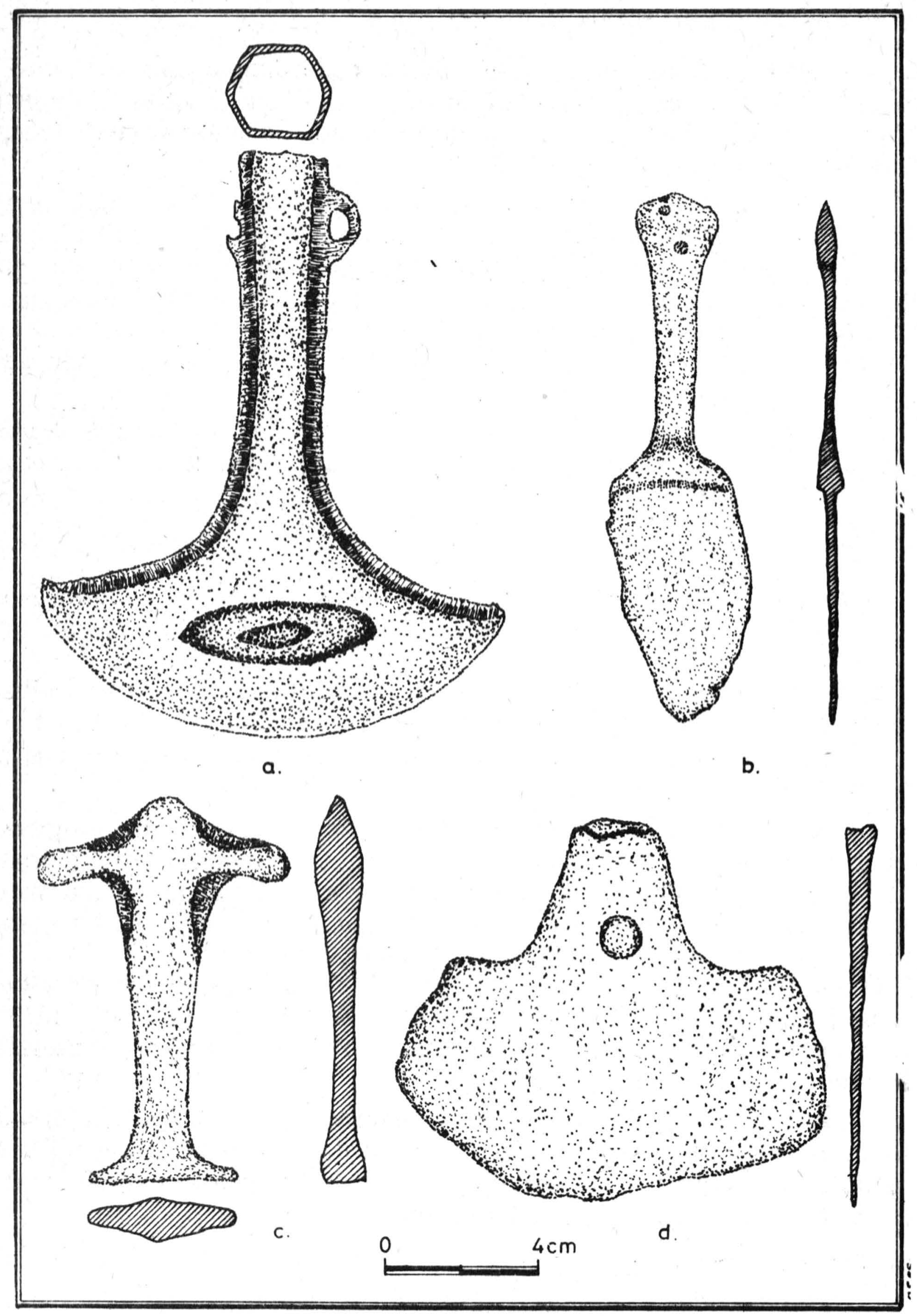

Gambar 11: Alat-alat perunggu dari Kwadeware (d.Sentani) a. kapak : b.pisau; c.tangkai pișau; fr. kapak 
letak kedua daerah itu saling berjauhan, tetapi menunjukkan persamaan metoda pembuatan, yaitu tidak memakai roda pemutar (potter's wh sl). Pembuatan periuk di pulau Mansinam sudah jarang dilakukan, karena hanya melayani pesanan saja. Pembuat periuk (kundi) terdiri dari kı.um wanita. Salah satu jenis periuk yang disebut bakon, mempunyai dasar rata. Di bawah bibir dihiasi, dengan hias gores yang bermotif meander tegaktgambar: 12. a). Hiasan periuk disebut famanggor.

Pembuatan periuk di kampung Abar, defigan menggunakan metoda coiling. Untuk memperoleh bentuk periuk yang diinginkan, pola periuk itu disempurnakan dengan kayu pemukul/yanggalu dan dengan batu penahan/ruka (gambar: 12. c.d). Periuk yang dihasilkan mempunyai dasar bulat, yang disebuthelai dengan hiasan gores yang terletak di bagian bawah bibir periuk (gambar: 12. b).

Pada waktu periuk dibakar, si tukang bakar tidak boleh beringus, demikian pula anak-anak dilarang menangis. Apabila pantangan ini dilanggar, maka akan mengakibatkan periuk-periuk yang dibakar menjadi pecah.

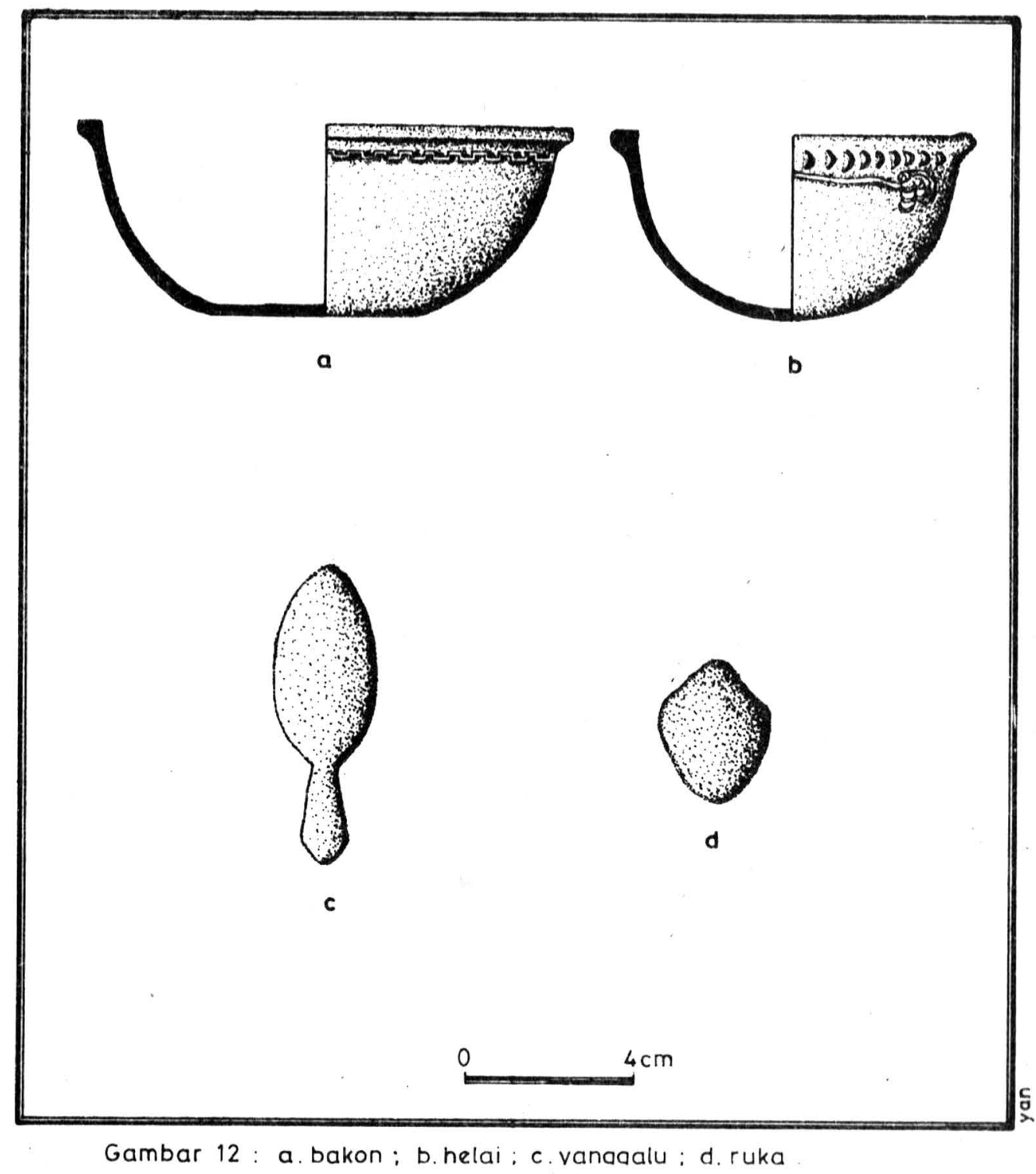




\section{BEBERAPA PENDAPAT}

Irian Jaya mempunyai potensi kepurbakalan yang cukup besar, khususnya peninggalan-peninggalan prasejarah bersama tradisinya yang masih hidup sampai saat ini. Dengan adanya tradisi-tradisi itu akan membingungkan kita dalam memberikan analisa temuan baik pertanggalan maupun tipologi dan sebagainya. Para prehistorisi akan menemui kesukäran apabila suatu ketika menemukan situs bekas tempat tinggal orang Timorini atau suku bangsa lain yang masih mempunyai tingkat kebudayaan neolithik.

Lukisan-lukisan dinding tebing menurut pendapat saya tidak mudah ditentukan umurnyc., apalagi cara penentuan umur seperti yang dikemukakan oleh J. Roder dan Galis tersebut.

Dasar penentuan umur suatu lukisan dinding tebing/gua tidak dapat ditinjau dari satu segi saja, yaitu warna. Warna yang menutup warna lainnya pada suatu lukisan dinding gua/tebing tidak selamanya berumur lebih muda. Tetapi harus dipertimbangkan faktor-faktor lain misalnya maksud dan alam yang menyediakan bahan pokok warna, yang terdapat di sekelilingnya.

Analisa khemis terhadap bahan warna itu mungkin akan dapat membantu memberikan pertanggalan terhadap lukisan-lukisan itu. Demikian pula halnya tengan adanya pengamatan terhadap perubahan permukaan air laut yang pernah mengabrasi dinding tebing atau gua bersangkutan akan sangat membantu. Ceritera rakyat tentang adanya lukisanlukisan itu memang tidak dapat dipercaya seluruhnya, tetapi pada hemat saya ada salah satu segi penting daripadanya yang dapat membantu memberikan pertanggalan. Tokoh nenek moyang yang datang dari arah matahari terbit misalnya, mungkin dapat dihubungkan dengan adanya migrasi suatu bangsa yang datang dari arah timur. Kejadian ini dapat dijadikan bahan pertimbangan dalam memberiká. per janggalan terhadap lukisan-lukisan itu.

Dengan adanya kenyataan-kenyataan itu, maka penelitian arkeologis di Irian Jaya masih perlu dilakukan secara intensif, misalnya dengan mengadakan ekskavasi-ekskavasi pada beberapa gua secara lebih mendalam dan penganalisaan hasil temuan secara tuntas. Tentu saja dalam pengolahan data dari hasil penelitian itu harus dilakukan oleh beberapa disiplin yang berhubungan dengan ilmu arkeologi, seperti geologi; biologi dan sebagainya.

Dari hasil penelitian yang tuntas itu, maka suatu hasil yang matang akan dapat dijadikan sebagai dasar penganalisaan dan bahan pembànding dengan daerah-daerah lain di Indonesia atau dengan negaranegara tetangga yang terdekat. 


\section{DAFTAR BACAAN}

Bachtiar, Harsja W.

Bintarti, D.D.

1980

Gunawan Wiradi \& Sugeng Handjojo 1962

Heekeren, H.R. van 1972

Koentjaraningrat

1963

1963 .

Soejono, R.P. 1963
"Sejarak Irian Barat", Penduduk Irian Barat, P.T. Penerbitan Universitas. Barat, P.T. Penerbitan Universitas. "Mungkinkah Doyo Lama sebagai situs Megalithik",Pertemuan Ilmiah Arkeologi II (belum terbit).

"Tanah dan Pertanian di Irian Barat", Irian Barat, Staf Penguasa Perang Tertinggi.

The Stone Age of Indonesia, Verhandelingen van het Koninklijk Instituut voor Taal-, Land-en Volkenkunde, 61.

"Lingkungan Alam", Pen duduk Irian Barat, P.T. Penerbitan Universitas.

"Orang Timorini”, ,Penduduk Irian Barat, P.T. Penerbitan Universitas.

"Prehistori Irian Barat", Penduduk irian Barat, P.T. Penerbitan Universitas. 